\title{
PENGARUH MODEL PEMBELAJARAN PROBLEM BASED LEARNING (PBL) DENGAN PENGGUNAAN MULTIMEDIA TERHADAP HASIL BELAJAR SISWA MADRASAH ALIYAH
}

\section{THE EFFECT OF PROBLEM BASED LEARNING (PBL) MODEL WITH THE USE OF MULTIMEDIA ON THE LEARNING OUTCOMES OF MADRASAH ALIYAH STUDENTS}

\author{
Fuadaturrahmah $^{* 1}$, Yumira Simamaora ${ }^{2}$ \\ ${ }^{1}$ Akademi Maritim Belawan \\ ${ }^{2}$ Universitas Alwashliyah Medan \\ *Corresponding author: fuadaturrahmah01@gmail.com
}

\begin{abstract}
ABSTRAK
Penelitian ini bertujuan untuk mengetahui pengaruh model pembelajaran Problem Based Learning (PBL) dengan bantuan Media animasi computer dan LKS Terhadap Hasil Belajar (Kognitif, Psikomotor, Dan Afektif) Kimia Siswa. Populasi dalam penelitian ini adalah seluruh kelas XI IPA MA. LAB UIN SU Medan yang terdiri dari 2 kelas dengan total siswa 60 siswa. Adapun sampel yang diambil satu kelas yaitu kelas XI IPA 1 sebanyak 30 siswa/kelas. Instrument yang digunakan untuk mengetahui hasil kognitif adalah test objektif dalam bentuk pilihan ganda sebanyak 23 soal yang sudah valid. Berdasarkan analisis data hasil belajar diperoleh bahwa rata-rata hasil belajar siswa adalah 37,0 \pm 8,5 dan setelah diberikan pembelajaran melalui model pembelajaran Problem Based Learning (PBL) dengan bantuan media animasi komputer dan LKS diperoleh hasil belajar siswa sebesar 87,0 \pm 7,5 denga rata-rata gain sebesar 0.81. diperoleh data kognitif (Post Test : 87,0 \pm 7,5 dan gain $81 \%$ ), data afektif $81 \pm 4,7$ sedangkan data psikomotor $86 \pm 6,8$. Peningkatan hasil belajar kimia siswa yang signifikan sebesar $81 \%$. Hasil pengujian hipotesis diperoleh harga $t_{\text {hitung }}>t_{\text {tabel }}$ yaitu 4,38 $>$ 1,699 dengan taraf signifikasi 5\% $(\alpha=0,05)$ sehingga Ha diterima yang berarti dapat disimpulkan ada pengaruh model pembelajaran Problem Based Learning (PBL) dengan bantuan media animasi komputer dan LKS terhadap hasil belajar kimia siswa.
\end{abstract}

Kata Kunci: Problem Based Learning (PBL); Media; Hasil Belajar.

\begin{abstract}
This study aims to determine the effect of the Problem Based Learning (PBL) learning model with the help of computer animation media and worksheets on student chemistry learning outcomes (cognitive, psychomotor, and affective). The population in this study were all class XI IPA MA. LAB UIN SU Medan which consists of 2 classes with a total of 60 students. The sample taken is one class, namely class XI IPA 1 as many as 30 students/class. The instrument used to determine cognitive results is an objective test in the form of multiple choice as many as 23 questions that are already valid. Based on the analysis of learning outcomes data, it was obtained that the average student learning outcomes were $37.0+8.5$ and after being given learning through the Problem Based Learning $(P B L)$ learning model with the help of computer animation media and worksheets, the student learning outcomes were $87.0+7.5$ with an average gain of 0.81. Cognitive data obtained (Post Test: $87.0+7.5$ and gain 81 $\%)$, affective data $81+4.7$ while psychomotor data $86+6.8$. The significant increase in student chemistry learning outcomes is $81 \%$. The results of testing the hypothesis obtained that the price
\end{abstract}


tcount $>$ ttable is $4.38>1.699$ with a significance level of $5 \%(\alpha=0.05)$ so that Ha is accepted which means it can be concluded that there is an effect of the Problem Based Learning (PBL) learning model with the help of computer animation media and worksheets. on student chemistry learning outcomes.

Keywords: Problem Based Learning (PBL); Media; Learning Outcomes.

\section{PENDAHULUAN}

Pembelajaran merupakan suatu kegiatan yang melibatkan seseorang dalam upaya memperoleh pengetahuan, keterampilan dan nilai-nilai positif dengan memanfaatkan berbagai sumber untuk belajar. Pembelajaran dapat melibatkan dua pihak yaitu siswa sebagai pembelajar dan guru sebagai fasilitator. Kegiatan terpenting dalam pembelajaran adalah proses belajar (learning proses). Proses belajar memiliki beberapa ciri berikut: (1) Belajar sifatnya disadari, dalam hal ini siswa merasa bahwa dirinya sedang belajar, timbul dalam dirinya motivasi untuk memiliki pengetahuan yang diharapkan. (2) Hasil belajar diperoleh dengan adanya proses, dalam hal ini pengetahuan diperoleh secara tidak spontanitas, instant, melainkan bertahap.

Mengajar kimia tidak mudah dan penuh dengan tantangan. Tantangan tersebut lahir akibat dari berbagai perkembangan iptek yang sangat dinamis. Munculnya pemikiran baru terhadap konsep kimia, meluasnya produk aplikasi kimia di masyarakat, berkembangnya teori-teori pembelajaran, dan tuntutan masyarakat, menjadikan perlunya pengkajian ulang tentang pemahaman, sudut pandang, serta tradisi guru dalam mengajar kimia..

Pengalaman pendidikan yang sering dihadapi guru-guru kimia di SMA adalah bahwa kebanyakan siswa menganggap pelajaran kimia sebagai mata pelajaran yang sulit, sehingga siswa terlebih dahulu merasa kurang mampu untuk mempelajarinya. Hal ini mungkin disebabkan oleh penyajian materi kimia yang kurang menarik dan membosankan, akhirnya terkesan menakutkan bagi siswa, akibatnya banyak siswa yang kurang menguasai konsep dasar kimia. Sebagai akibat dari merasa sulit maka pelajaran kimia menjadi tidak menarik lagi bagi siswa. Dan ini yang menjadi salah satu faktor penyebab rendahnya hasil belajar siswa selama ini.

Banyak kritikan terhadap proses dan hasil pembelajaran kimia di sekolah menengah atas termasuk madrasah aliyah. Sejumlah kritik terarah pada kegiatan belajar mengajar yang berpusat pada guru sehingga pembelajaran nampak sebagai ceramah dan sifatnya monoton, yang didalamnya pengetahuan baik fakta, konsep, prinsip dan teori kimia di transmisikan dari guru tanpa menstimulasi peserta didik untuk berpikir atau bernalar. Karakter ilmu kimia sebagai "eksperimental science" tidak tampak dalam kegiatan belajar mengajar kimia, karena sangat jarang siswa distimulasi untuk melakukan observasi terhadap fenomena kimia.

Kenyataan yang terjadi di lapangan masih ada guru yang mengajar siswa tanpa mengevaluasi hasil belajarnya. Lemahnya proses pembelajaran dan rendahnya prestasi hasil belajar siswa, mengakibatkan siswa malas dan kurang berminat belajar, sehingga kreativitasnya rendah, dan berpengaruh pada perkembangan kognitifnya. Oleh karena itu perlu upaya meningkatkan minat belajar dan kreativitas siswa dengan cara memberdayagunakan fasilitas atau sumber-sumber belajar seperti media yang tepat serta pemilihan strategi pembelajaran yang tepat..

Agar penerapan model pembelajaran lebih mudah dan menarik dalam implementasinya,maka disajikan dengan media animasi dan LKS. Melalui pemanfaatan lembar kerja ini diharapkan siswa mampu berpikir, mencoba menyelesaikan soal, dan ketika menghadapi kesulitan bisa mengungkapkan dan berdiskusi dengan teman atau guru. Dan penggunaan animasi dengan bantuan komputer sebagai media pembelajaran yang memiliki banyak kelebihan dan dapat menambah kesan realisme dan merangsang siswa untuk merespon dengan adanya warna dan grafiks. Media animasi merupakan media yang berupa gambar yang bergerak yang disertai dengan suara dan merupakan perkembangan dari IPTEK. 
Hasil penelitian menunjukkan bahwa penggunaan media pembelajaran secara signifikan meningkatkan hasil belajar kimia siswa. Media memudahkan siswa memahami konsep-konsep kimia sehingga dapat meningkatkan motivasi belajar siswa yang pada akhirnya akan memberi kesan pembelajaran yang lebih lama diingat siswa (Situmorang dan Silitonga, 2009). Menurut Sipayung (2009), Hasil belajar siswa yang menggunakan media komputer lebih baik secara signifikan dibandingkan dengan hasil belajar siswa tanpa menggunakan media komputer. Penelitian Situmorang (2006) menunjukkan bahwa inovasi pembelajaran menggunakan komputer dapat meningkatkan prestasi belajar mahasiswa. Efektivitas pembelajaran menggunakan komputer terhadap prestasi belajar mahasiswa sebesar $82 \%$ dan pembelajaran dengan menggunakan komputer meningkatkan daya ingat terhadap penguasaan materi pelajaran dibandingkan terhadap pembelajaran dengan menggunakan metode ceramah. Hasil penelitian Sebayang (2007) menyatakan bahwa hasil belajar siswa yang menggunakan media ajar lebih tinggi dari pada tanpa media ajar. Hasil belajar siswa yang dibelajarkan dengan media lebih baik 86,7\% dari pada tanpa menggunakan media (Saragih : 2008).

\section{METODE PENELITIAN}

\subsection{Lokasi Penelitian}

Penelitian ini dilakukan di sekolah MA. LAB UIN SU Medan, yang berlokasi di jalan William iskandar pasar V Medan estate.

\subsection{Populasi dan Sampel Penelitian}

Populasi penelitian adalah seluruh kelas reguler MA. LAB UIN SU Medan yang terdiri dari 2 kelas yang setiap kelas terdiri dari 30 siswa/kelas.

Penentuan sampel menggunakan teknik Purpossive sampling. Pengambilan sampel didasarkan atas tujuan tertentu. Teknik ini dilakukan karna beberapa pertimbangan tertentu, sehingga tidak dapat mengambil sampel yang besar dan jauh. Sampel kelas diambil hanya 1 kelas yaitu kelas XI IPA 1 yang diberi pengajaran menggunakan model Pembelajaran Problem Based Learning (PBL) dengan bantuan media animasi komputer dan LKS. Selanjutnya, Penentuan sampel siswa dilakukan secara purpossive sampling dengan kemampuan siswa yang relatif sama dengan jumlah siswa 30 orang. Jumlah siswa yang dijadikan sampel diperoleh melalui data hasil pretest sehingga diperoleh data yang homogen dengan kemampuan intelegensi yang hampir sama.

\subsection{Instrumen Penelitian}

Instrumen penelitian ini meliputi instrumen tes dan non tes. Tes yang dilakukan dalam bentuk pilihan ganda yang telah distandarisasi dengan cara diuji coba terlebih dahulu. Instrumen tes ini terdiri dari 23 soal yang valid dengan option (a, b, c, d dan e).

Sedangkan dalam bentuk non tes yakni dengan observasi untuk mengetahui afektif (sikap) dan psikomotor (keterampilan) siswa.

\subsection{Analisis Instrumen Non-tes}

Dalam penelitian ini, instrument non-tes yaitu lembar observasi penilaian sikap (afektif) dan keterampilan (psikomotor).

\subsection{Rancangan Penelitian}

Rancangan penelitian yang digunakan adalah One Group Pretest-Posttest Design yang terdiri dari satu kelompok kelas. Paradigma dalam penelitian model One Group Pretest-Posttest Design dapat dilihat pada gambar.

$$
\mathrm{T}_{1} \quad \mathrm{X} \quad \mathrm{T}_{2}
$$

Gambar 1. Model One Group Pretest-Posttest Design 
Keterangan :

$\mathrm{X} \quad=$ Perlakuan yang diberikan dengan model Problem Based Learning (PBL) dengan bantuan media Animasi komputer dan LKS

$\mathrm{T}_{1} \quad=$ Nilai $/$ hasil pengamatan kelompok eksperimen pada awal penelitian

$\mathrm{T}_{2} \quad=$ Nilai / hasil pengamatan kelompok eksperimen pada akhir penelitian

\subsection{Teknik Analisis Data}

Perangkat yang akan digunakan untuk mengolah dan menganalisis data yaitu software Microsoft Excel.

Adapun langkah-langkah pengolahan data adalah sebagai berikut:

1. Menghitung rata-rata masing-masing kelompok dengan menggunakan rumus:

2. Uji Normalitas

$$
\overline{\mathrm{X}}=\frac{\sum \mathrm{x}}{\mathrm{n}}
$$

Uji ini bertujuan untuk melihat apakah sampel berdistribusi normal atau tidak. Pengujian ini dilakukan dengan uji Chi Kuadrat (Silitonga, P.M. 2011) dengan langkah sebagai berikut ;

- Menentukan nilai chi kuadrat dengan menjumlahkan semua nilai $\frac{\left(f_{0}-f_{h}\right)^{2}}{f_{h}}$

- Membandingkan harga Chi Kuadrat hitung $\left(\mathrm{X}^{2}\right)$ dengan harga Chi Kuadrat tabel pada $\alpha=0,05$ dengan $\mathrm{db}=5$

- Jika Chi Kuadrat hitung $\left(X^{2}\right)<$ harga Chi Kuadrat tabel maka data tersebut berdistribusi normal.

3. Uji Homogenitas

Uji ini digunakan untuk mengetahui tingkat berpencarnya data kuantitatif dalam satu kelompok data,dapat dilakukan dengan melihat ukuran simpangan yang terjadi dengan menggunakan rumus :

\section{Uji Hipotesis}

$$
\mathrm{S}=\sqrt{\frac{\Sigma\left(\mathrm{x}_{\mathrm{i}}-\mathrm{X}^{2}\right.}{(\mathrm{N}-1)}}
$$

Setelah melakukan analisis data diperoleh data yang berdistribusi normal dan data homogenitas. Maka uji hipotesis yang digunakan adalah uji t pihak kanan untuk satu kelompok sampel sebagai berikut :

$\mathrm{H}_{\mathrm{o}}: \mu \leq \mu_{0}$

$\mathrm{H}_{\mathrm{a}}: \mu>\mu_{0}$

Keterangan :

$\mu \quad$ : Rata-rata hasil belajar kimia siswa yang di berikan pengajaran model pembelajaran Problem

Based Learning (PBL) dengan bantuan media animasi komputer dan LKS.

$\mu_{0} \quad$ : nilai yang hipotesiskan.

Dengan menggunakan rumus :

$$
\mathrm{t}_{\text {hitung }}=\frac{\bar{X}-\mu 0}{s / \sqrt{n}}
$$

Kriteria pengambilan keputusan dalam pengujian hipotesis adalah "Jika harga t-hitung terletak pada daerah kritis (daerah penolakan $H_{0}$ ) maka keputusan yang harus diambil adalah : Tolak $H_{0}$ yang berarti terima Ha.

Dimana :

$$
\begin{array}{ll}
\bar{X} & =\text { skor rata-rata peningkatan hasil belajar kelompok eksperimen } \\
\mu_{0} & =\text { nilai yang hipotesiskan } \\
\mathrm{n} & =\text { jumlah sampel eksperimen } \\
\mathrm{S} & =\text { varians sampel kelompok eksperimen }
\end{array}
$$


5. Peningkatan Hasil Belajar

Menurut Meltzer (dalam Suyanti, 2006) persen peningkatan hasil belajar dapat dihitung dengan rumus $\mathrm{g}$ faktor (gain score ternormalisasi). Rumus g faktor digunakan untuk mengetahui perolehan hasil belajar siswa.

Persentase peningkatan hasil belajar dapt dihitung langsung dicari rata-rata nilai seluruh siswa untuk masing-masing kelas.

Rumus g faktor yang digunakan adalah sebagai berikut:

$$
\% \mathrm{~g}=\frac{\text { nillai post test-nillai pre test }}{\text { nilai maksimum-nilai pretest }} \times 100
$$

Harga peningkatan $(\mathrm{g})$ dari masing-masing siswa kemudian dirata-ratakan dengan rentangan:

$\mathrm{g}<0,3$ : hasil belajar rendah

$0,3 \leq \mathrm{g} \leq 0,7 \quad$ : hasil belajar sedang

$\mathrm{g}>0,7 \quad$ : hasil belajar tinggi

\section{HASIL DAN PEMBAHASAN}

\subsection{Data Hasil Penelitian}

Berdasarkan hasil penelitian diperoleh data pre-tes dan data post-tes. Berdasarkan hasil perhitungan yang telah dilakukan. Diperoleh nilai rata-rata pre-tes, pos-tes dan gain kelas eksperimen yang terangkum dalam tabel 1 dibawah ini

Tabel 1. Data Hasil Penelitian

\begin{tabular}{|c|c|c|c|c|c|c|c|c|c|}
\hline \multicolumn{2}{|c|}{ Pre-tes } & \multicolumn{2}{|c|}{ Post - tes } & \multicolumn{2}{|c|}{ Afektif } & \multicolumn{2}{|c|}{ Psikomotor } & \multicolumn{2}{|c|}{ Gain } \\
\hline $\bar{X}$ & SD & $\overline{\bar{X}}$ & SD & $X$ & SD & $X$ & SD & $\bar{X}$ & SD \\
\hline 37 & 8,5 & 87 & 7,5 & 81 & 4,7 & 86 & 6,8 & 0,81 & 0,094 \\
\hline
\end{tabular}

Berdasarkan data diatas dapat dilihat bahwa rata-rata peningkatan hasil belajar (gain) pada kelas eksperimen mengalami peningkatan yang signifikan. Adapun data hasil belajar dapat dilihat pada grafik di bawah ini :

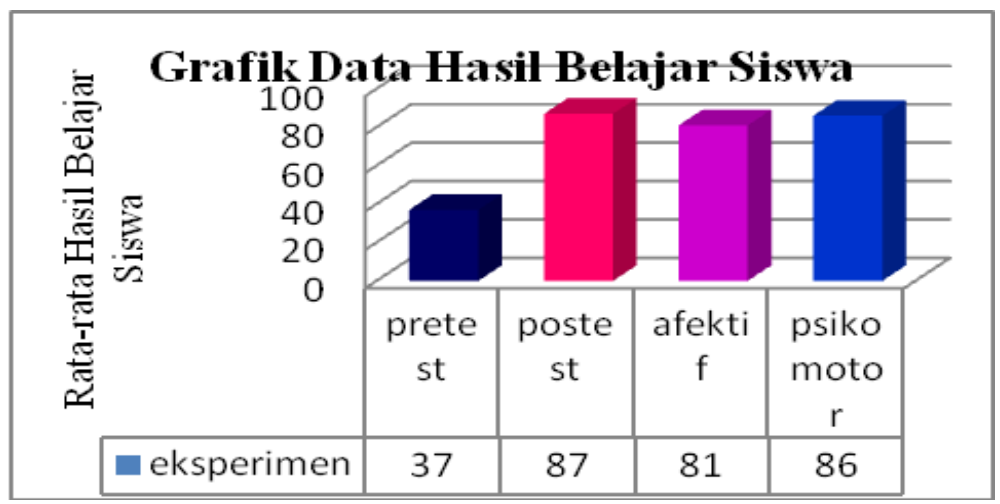

Gambar 1. Grafik Data Hasil Belajar Siswa 


\subsection{Analisis Data Penelitian}

Uji Normalitas Data

Uji normalitas digunakan untuk mengetahui normal tidaknya populasi penelitian tiap variabel penelitian. Uji normalitas dilakukan dengan uji Chi Kuadrat. Hasilnya dirangkum pada tabel 3.

Tabel 2. Normalitas Data Hail Belajar dan Gain

\begin{tabular}{ccccccc}
\hline \multicolumn{2}{c}{ Kognitif } & Afektif & Psikomotor & Gain & & Ket \\
\cline { 1 - 5 } Pre- test & Post - test & & & & & \\
\hline$\left(X^{2}\right)_{\text {hitung }}$ & $\left(X^{2}\right)_{\text {hitung }}$ & $\left(X^{2}\right)_{\text {hitung }}$ & $\left(X^{2}\right)_{\text {hitung }}$ & $\left(X^{2}\right)_{\text {hitung }}$ & $\left(X^{2}\right)_{\text {tabel }}$ & Data \\
\hline 5,65 & 2,9 & 1,45 & 1,25 & 7,92 & 11,07 & normal \\
\hline
\end{tabular}

Uji normalitas yang digunakan adalah Uji Chi Kuadrat. Pengujian ini dilakukan dengan membandingkan harga Chi Kuadrat $\left(X^{2}\right)_{\text {hitung }}$ dengan harga Chi Kuadrat $\left(X^{2}\right)_{\text {tabel }}$ pada tingkat signifikan $\alpha=0,05$ dengan $\mathrm{db}=5$. Berdasarkan ketentuan jika $\left(X^{2}\right)_{\text {hitung }}<\left(X^{2}\right)_{\text {tabel }}$, maka data terdistribusi normal.

\section{Uji Homogenitas Data}

Uji homogenitas digunakan untuk mengetahui tingkat berpencarnya data kuantitatif dalam satu kelompok data. Uji homogenitas diperlukan untuk menganalisis data lanjutan, sehingga terhadap data dapat dilakukan uji t. Uji homogenitas satu kelompok sampel yang dilakukan dengan cara menghitung simpangan baku (standar deviasi) dan jika dikuadratkan maka disebut varians. Uji homogenitas hasil belajar disajikan pada tabel 4 dibawah ini:

Tabel 3.Homogenitas Data Hasil Belajar dan Gain

\begin{tabular}{|c|c|c|c|c|c|}
\hline \multicolumn{2}{|c|}{ Kognitif } & \multirow[t]{2}{*}{ Afektif } & \multirow[t]{2}{*}{ Psikomotor } & \multirow[t]{2}{*}{ Gain } & \multirow{2}{*}{ Ket } \\
\hline Pre- test & Post - test & & & & \\
\hline Varians $\left(\mathrm{S}^{2}\right)$ & Varians $\left(S^{2}\right)$ & Varians $\left(S^{2}\right)$ & Varians $\left(S^{2}\right)$ & Varians $\left(\mathrm{S}^{2}\right)$ & Homogen \\
\hline 72,3 & 56,25 & 22,09 & 46,24 & 0,009 & \\
\hline
\end{tabular}

\section{Uji Hipotesis}

Setelah diketahui bahwa data terdistribusi normal dan homogen maka dapat dilakukan uji hipotesis dengan menggunakan uji statistik uji t. Uji ini untuk mengetahui apakah hipotesis dalam penelitian ini diterima atau ditolak. Kriteria pengujian jika $t_{\text {hitung }}>t_{\text {tabel }}$ maka hipotesis alternatif diterima dan hipotesis nihil atau hipotesis nol ditolak. Data hasil uji hipotesis dapat dilihat pada tabel 5. dibawah ini :

Tabel 4. Hasil Uji Hipotesis Data Hasil Belajar

\begin{tabular}{ccccc}
\hline $\begin{array}{c}\text { Data Kelas } \\
\text { Eksperimen }\end{array}$ & $\begin{array}{c}\mu \text { (nilai yang } \\
\text { dihipotesiskan) }\end{array}$ & $\mathrm{t}_{\text {hitung }}$ & $\mathrm{t}_{\text {tabel }}$ & Keterangan \\
\hline $\mathrm{X}=85$ & 80 & 4,38 & 1,699 & $\begin{array}{c}\text { Ha diterima, } \\
\text { Ho ditolak }\end{array}$ \\
$\begin{array}{c}\mathrm{SD}=6,3 \\
\mathrm{~S}^{2}=41,52\end{array}$ & & & & \\
\hline
\end{tabular}

Dari data distribusi $\mathrm{t}$ diperoleh $\mathrm{t}$ tabel $=1,699$. sedangkan berdasarkan perhitungan diperoleh $\mathrm{t}$ hitung $=4,38$ sehingga harga $\mathbf{t}_{\text {hitung }}>\mathbf{t}_{\text {tabel }}(4,38>1,699)$. Dengan demikian kriteria pengujian hipotesis $t_{\text {hitung }}>t_{\text {tabel }}$ terpenuhi. Artinya $\mathrm{H}_{0}$ ditolak, Ha diterima yang berarti ada pengaruh model pembelajaran Problem Based Learning (PBL) dengan bantuan media animasi komputer dan LKS terhadap hasil belajar kimia siswa pada materi sistem koloid. 


\section{Persentase Peningkatan Hasil Belajar}

Hasil perhitungan persentase peningkatan hasil belajar dapat langsung dicari dari rata-rata nilai gain seluruh siswa untuk masing-masing kelas dapat dilihat pada tabel dibawah ini :

Tabel 5. Persen Peningkatan Hasil Belajar

\begin{tabular}{|c|c|c|c|c|}
\hline Kelas & Kriteria & Ket : & G & Ket \\
\hline Eksperimen & $\begin{array}{l}\mathrm{G}<0,3=\text { Rendah } \\
0,3<\mathrm{G}>0,7=\text { Sedang } \\
\mathrm{G}>0,7=\text { Tinggi }\end{array}$ & $\begin{array}{c}\Sigma \mathrm{g}=24,32 \\
\Sigma \mathrm{g}=0,81\end{array}$ & $81 \%$ & Tinggi \\
\hline
\end{tabular}

Berdasarkan tabel di atas dapat dilihat bahwa besar peningkatan hasil belajar pada kelas eksperimen sebesar $81 \%$ dan termasuk kriteria tinggi,.

\subsection{Pembahasan}

Berdasarkan analisis data hasil belajar dalam penelitian sebelum dilakukan perlakuan yang berbeda kepada kedua kelas sampel diperoleh bahwa rata-rata hasil belajar siswa kelas eksperimen adalah 37,0 \pm 8,5 dan setelah diberikan pembelajaran melalui model pembelajaran Problem Based Learning (PBL) dengan bantuan media animasi komputer dan LKS diperoleh hasil belajar siswa sebesar $87,0 \pm 7,5$.

Pada saat pembelajaran berlangsung di kelas eksperimen peneliti menggunakan pembelajaran Problem Based Learning (PBL) dengan bantuan media animasi komputer dan LKS pada materi Sistem Koloid. Namun, sebelum dilakukan pembelajaran peneliti membagi siswa ke dalam kelompok. Dimana tiap-tiap anggota kelompok terdiri atas 7 siswa. Peneliti membagikan media LKS kepada setiap kelompok sebagai bahan bacaan atau literatur dan menyelesaikan masalah pada LKS. Adapun tujuan model pembelajaran ini adalah menuntut siswa untuk menyadari bahwa banyak hal di lingkungan sekitarnya perlu untuk dianalisis kebenarannya, khususnya yang berhubungan dengan pelajaran kimia. Model problem based learning menuntut siswa untuk berpikir tingkat tinggi yaitu berpikir kritis untuk menganalisis masalah yang diberikan. Selain ada tahap yang paling memberikan dorongan dan interaksi antar siswa yaitu pada tahap belajar kelompok dengan pemecahan masalah yang berbeda-beda. Seluruh siswa dilatih untuk menjadi pembelajar yang mandiri dan juga mampu bekerjasama dengan teman satu kelompoknya. Hal ini mendorong mereka mengajukan pertanyaan, mencari penyelesaian terhadap masalah yang kongkrit oleh kelompok maupun sendiri dan menyelesaikan tugas-tugas tersebut secara mandiri dan kelompok serta mengembangkan kemampuan berpikir kritis untuk terbiasa memecahkan masalah secara ilmiah. Pada tahap ini masing-masing kelompok berperan aktif untuk saling berdiskusi dalam mengerjakan lembar analisis yang telah disediakan, sehingga pola berpikir siswa saling terhubung antara satu dengan yang lain. Model problem based learning terdiri dari lima tahapan yaitu orientasi peserta didik kepada masalah, mengorganisasikan peserta didik, membimbing penyelidikan individu dan kelompok, mengembangkan dan menyajikan hasil karya dan menganalisa serta mengevaluasi proses pemecahan masalah.

Penyajian masalah nyata yang terdapat dalam LKS dikerjakan siswa secara berkelompok. Pada saat siswa menyelesaikan LKS siswa terlihat begitu antusias dan termotivasi sehingga membuat siswa lebih aktif dan dapat mengembangkan kemampuan nya pada proses belajar mengajar. Siswa saling bertukar pendapat dalam berdiskusi mengerjakan lembar kerja yang diberikan. Peneliti membimbing dan mengontrol tiap kelompok dengan cara menghampiri masing-masing kelompok dan menanyakan apakah ada kesulitan. Kemudian setelah berdiskusi, peneliti memberikan kesempatan kepada kelompok yang ingin mempersentasikan atau menampilkan hasil diskusi tersebut. Peneliti memberikan arahan dan pandangan terhadap konsep-konsep baru yang telah dimiliki oleh masing- 
masing kelompok dari hasil jawaban diskusi siswa dan memberikan penjelasan terhadap jawaban siswa yang belum tepat.

Hasil pengujian hipotesis diperoleh harga $t_{\text {hitung }}>t_{\text {tabel }}$ yaitu 4,38>1,699 dengan taraf signifikasi $5 \%(\alpha=0,05)$ sehingga Ha diterima yang berarti ada pengaruh model pembelajaran Problem Based Learning (PBL) dengan bantuan media animasi komputer dan LKS terhadap hasil belajar kimia siswa pada materi sistem koloid. Dari hasil perhitungan gain antara post-tes dan pre-tes kelas eksperimen diperoleh besarnya gain pada kelas eksperimen adalah $81 \%$.

Apabila dibandingkan dengan penelitian terdahulu oleh Situmorang (2014) menunjukkan bahwa ada pengaruh model PBL terhadap peningkatan hasil belajar siswa sebesar $61 \%$. Yulinarti, $d k k$ (2013) menunjukkan bahwa penerapan model pembelajaran berbasis masalah memberikan pengaruh baik terhadap prestasi belajar kimia siswa field independent dibandingkan dengan field dependent pada materi koloid. Mashuri (2014) menunjukkan bahwa kemampuan representasi siswa yang mempelajari larutan penyangga menggunakan media animasi sebesar 70,40\%. Freddy (2014) menunjukkan bahwa lebih bagus peningkatan hasil belajar dengan menggunakan media animasi. Lestari $d k k$ (2014) menunjukkan bahwa prestasi belajar aspek kognitif dengan menggunakan media animasi lebih meningkat. Maka berdasarkan penelitian yang telah dilakukan di MA. LAB UIN SU Medan dapat disimpulkan bahwa melalui penerapan model pembelajaran Problem Based Learning (PBL) dengan bantuan media animasi komputer dan LKS dapat meningkatkan hasil belajar siswa saat proses belajar mengajar berlangsung.

\section{KESIMPULAN DAN SARAN}

\subsection{Kesimpulan}

Berdasarkan hasil penelitian yang telah dilakukan, diambil beberapa kesimpulan sebagai berikut :

1. da pengaruh model pembelajaran Problem Based Learning (PBL) dengan bantuan media animasi komputer dan LKS terhadap hasil belajar kimia siswa dengan data kognitif (Post Test : 87,0 \pm 7,5 dan gain $81 \%$ ), data afektif $81 \pm 4,7$ sedangkan data psikomotor $86 \pm 6,8$ pada materi sistem koloid

2. Peningkatan hasil belajar kimia siswa yang signifikan menggunakan model pembelajaran Problem Based Learning (PBL) dengan bantuan media animasi komputer dan LKS terhadap hasil belajar kimia siswa adalah sebesar $81 \%$.

\subsection{Saran}

Berdasarkan kesimpulan dari hasil penelitian, maka penulis menyarankan hal-hal berikut :

1. Bagi guru atau calon guru disarankan untuk menggunakan model pembelajaran Problem Based Learning (PBL) dengan bantuan media animasi komputer dan LKS sebagai salah satu alternative pembelajaran untuk meningkatkan hasil belajar kimia siswa.

2. Adanya pengembangan dan tindak lanjut dalam pengembangan inovasi pembelajaran kimia pada materi-materi kimia lainnya.

3. Perlunya para guru dan calon guru memanfaatkan kemajuan teknologi untuk melihat perkembangan yang terjadi guna meningkatkan kreativitas dalam mendesain pembelajaran.

4. Perlu dilakukan penelitian lanjutan untuk materi pelajaran kimia yang berbeda sehingga dapat digunakan sebagai langkah dalam meningkatkan mutu pendidikan khususnya dalam bidang studi kimia. 


\section{DAFTAR PUSTAKA}

Arikunto, S., (2006), Prosedur Penelitian Suatu Pendekatan Praktik Edisi Revisi VI, Rineka Cipta, Jakarta.

Djamarah, S. B., (2011), Psikologi Belajar (Edisi Revisi), Rineka Cipta, Jakarta.

Djamarah, S. B., dan Zain A., (2006), Strategi Belajar Mengajar (Edisi Revisi), Rineka Cipta, Jakarta. Indah, F., Sukardjo, J. S., Utami, B., (2013), Penerapan Metode Teams Games Tournament (TGT) Dilengkapi Lembar Kerja Siswa (LKS) untuk Meningkatkan Aktivitas dan Prestasi Belajar Siswa Pada Pokok Bahasan Kelarutan dan Hasil Kali Kelarutan Kelas XI Semester Genap SMA Negeri 2 Sukoharjo Tahun Pelajaran 2012/2013, Jurnal Pendidikan Kimia, Vol 2 No 4 Tahun 2013: Hal 159-164..

Istarani, (2012), 58 Model Pembelajaran Inovatif, Media Persada, Medan.

Lestari, N. D., Ariani, S. R. D., Ashadi, (2014), Pengaruh Pembelajaran Kimia Menggunakan Metode Student Teams Achievement Divisions (STAD) Dan Team Assisted Individualization (TAI) Dilengkapi Media Animasi Terhadap Prestasi Belajar Siswa Pada Materi Asam Basa Kelas XI Semester Ganjil SMK Sakti Gemolong Tahun Pelajaran 2013/2014, Jurnal Pendidikan Kimia, Vol 3 No 1 Tahun 2014, Hal 44-50.

Mashuri, M. T., (2014), Upaya Peningkatan Representasi Peserta Didik Melalui Media Animasi Submikroskopik Untuk Materi Pokok Larutan Penyangga, Universitas Islam Kalimantan, Banjarmasin.

Ngalimun, (2014), Strategi dan Model Pembelajaran,Aswaja Pressindo, Yogyakarta.

Penggabean, F., Silaban, R., (2014), Pengaruh Penggunaan Media Animasi Komputer Terhadap Peningkatan Minat Dan Hasil Belajar Siswa Pada Pembelajaran Kesetimbangan Kimia, Unimed, Medan.

Silitonga, P. M., (2011), Metodologi Penelitian Pendidikan, FMIPA Unimed, Medan.

Situmorang, I. M., (2014), Pengaruh Model Problem Based Learning Terhadap Pembentukan Karakter dan Peningkatan Hasil Belajar Siswa Menggunakan Media Peta Konsep dengan Topik Konsep Mol, Unimed, Medan.

Suyanti, D. R., (2006), Strategi Pembelajaran Kimia, FMIPA Unimed, Medan.

Yulinarti, I., Andayani, Y., Savalas, T., (2013), Pengaruh Model Pembelajaran Berbasis Masalah Terhadap Kemandirian dan Prestasi Belajar Kimia Materi Pokok Koloid Ditinjau dari Gaya Kognitif Pada Siswa SMA Negeri 2 Mataram Tahun Ajaran 2012/2013, Universitas Mataram, Mataram. 